\title{
Workplace Management Lessons on Employee Recruitment Challenges, Furloughs, and Layoffs during the Covid-19 Pandemic
}

\author{
Bahaudin G. Mujtaba \\ Nova Southeastern University, Huizenga College of Business and Entrepreneurship, Fort Lauderdale, USA \\ Email: mujtaba@nova.edu
}

How to cite this paper: Mujtaba, B. G. (2022). Workplace Management Lessons on Employee Recruitment Challenges, Furloughs, and Layoffs during the Covid-19 Pandemic. Journal of Human Resource and Sustainability Studies, 10, 13-29.

https://doi.org/10.4236/jhrss.2022.101002

Received: January 20, 2022

Accepted: February 28, 2022

Published: March 3, 2022

Copyright $\odot 2022$ by author(s) and Scientific Research Publishing Inc. This work is licensed under the Creative Commons Attribution International License (CC BY 4.0).

http://creativecommons.org/licenses/by/4.0/

\begin{abstract}
The required quarantine and closure of thousands of public and private sector workplaces due to the Covid-19 coronavirus pandemic has changed jobs and life for millions of people around the globe due to layoffs and furloughs, along with certain management practices and strategies to keep workers coming to work and keeping them safe. Because of the required quarantine mandates, two years after the start of the pandemic, some departments and organizations are still having to close parts of their operations and facilities as they cannot find enough employees to keep up with the growing trends. Initially, in 2020, many organizations were laying off thousands of workers to prevent companies from going bankrupt. While some firms and managers terminated or laid off their employees through a very socially responsible or ethical means, others were not able to be as sensitive and, thus, are now suffering more from the shortage of experienced talent. Consequently, this article discusses some of the employee recruitment and retention challenges stemming from Covid-19 coronavirus and how managers and human resources professionals have learned to adjust their management practices to ethically and equitably lay off employees in the future, so that they can eventually attract, recruit, hire, develop, and retain dedicated workers once growth possibilities are available again.
\end{abstract}

\section{Keywords}

Covid-19, Layoffs, Recruitment, Compassion Fatigue, Pandemic Stress Impact

\section{Introduction}

Everyone in our modern society is affected by the Covid-19 coronavirus, whether at home or in the workplace. Worldwide, as of mid-January 2022, about 310 
million people had become infected with the Covid-19 virus and around 5.5 million people died because of it. While nearly 900,000 Americans have died due to Covid-19 complications thus far, millions of others have successfully recovered; yet many are still fighting the virus. Consequently, a record number of people during the last two years quit their jobs to be safe and healthy, or due to other reasons, which is labeled as the "Great Resignation" period. The good news is that many employees are returning to work or getting their jobs done remotely, while being emphatic toward the needs of their colleagues, but a few professionals are sad, anxious, and stressed as they never know when they could get infected by the virus or be in close contact or proximity of someone who tests positive for the infection. For example, this author knows of at least four close colleagues and relatives who tested positive for Covid-19 infection during the first week of 2022. As such, employers and employees alike are still suffering the consequences of this pandemic and will certainly have to remain more vigilant and flexible to retain workers that can get their jobs done as effectively as possible.

During the first four months of the Covid-19 infection, over 100,000 businesses in the United States of America closed their doors during the initial quarantine period. It is easy to see that the economic consequence of the Covid-19 coronavirus on people, jobs and politics for the United States and other nations have been dramatic and consequential (Jian, Wang, Wang, Lu, Wang, Zhang, \& Gong, 2020). Currently, in early January of 2022, we are seeing about 500,000 600,000 cases of Covid-19 infections most days in the United States. As such, many workers stay home to prevent the spread of the virus to their colleagues and customers. Consequently, most businesses are experiencing shortages of employees and are often forced to close for the day or cancel appointments. During the first few weeks of January, we are seeing thousands of flights in the U.S. being canceled every single day which is causing severe disruptions in people getting home, to work or even to school. Similarly, hospitalizations are rising again around the country, mostly from severe infections of those who are unvaccinated. For Americans, being unvaccinated is a choice as several FDA ("Food and Drug Administration" of the U.S.) approved vaccines are freely available in most pharmacies and nearby hospitals.

Medical professionals are having to continue to work around the clock and overtime just to provide care for their Covid-19 infected patients. The major complaint is that most of their patients are those who have purposely chosen to stay unvaccinated due to their personal, religious, or political reasons. Consequently, the concept of "compassion fatigue" is something that a few healthcare professionals might be experiencing since the vaccine has been available for over a year, yet many individuals are consciously choosing not to get it. It is not just the healthcare industry workers that are facing with such attitudinal challenges, but others are going through it as well; consequently, human resource (HR) professionals, trainers and managers need to provide reminders regarding empathy and even empathic listening skills for those who are in pain. As one example, 
United Airlines "required about 30,000 of its employees to take compassion training to improve the airlines service" (Parsi, 2021: p. 56), since as we have seen more cases of misbehaving and unruly passengers in this industry.

Most people go into the medical profession as they have an internal drive and passion to care for people, to help others, and to make this world a better place for all. Yet, when they see the irony that vaccines which can prevent people from getting the coronavirus infection is available, yet many are choosing not to get it and eventually become severely ill, thereby end up in the hospital to be taken care of by the already stressed and overworked healthcare professionals; consequently, it is natural that eventually some professionals are likely to experience compassion fatigue for the unvaccinated. The same level of compassion fatigue is something that the general population might experience regarding their coworkers and colleagues who are choosing not to get vaccinated. Some professionals are choosing not to get the vaccine and not go to work; these individuals don't want to get sick, but at the meantime a few of them are not being productive as they are quarantining voluntarily. In some cases, employers have been forcing workers to quarantine as they might have been in close contact with a colleague, vendor, supplier, or customer who became infected with the Covid-19 coronavirus.

With the spread of the omicron variant, millions of Americans were being infected each week in early weeks of 2022 and thousands hospitalized, which meant there were many individuals who were in close-contact with a Covid-19 positive person. An important part of reducing the spread of this infectious variant is timely testing and contact tracing; otherwise, workplace disruptions will continue to be high and stressful for both employees and consumer groups. Personal experience and observations during December of 2021 to January of $2022 \mathrm{dem}$ onstrated that while tourists coming to Thailand were able to get a PCR test for the Covid-19 infection as part of their "Test and Go" program at hotels and have their printed results back in less than ten hours, in the United States an appointment for the same test had to be made five days in advance through major chains such as CVS and Walgreens and the results took four days to arrive. So, once an American is sick or experiences any symptoms, he or she will then try to get tested which in the author's case was five days later plus four more days of waiting to get the results back, equaling 9 or more days in total. Of course, during these 9 days, many friends, family members and colleagues could easily be infected with the coronavirus. The lesson is that American leaders and policy makers can and must learn from the best practices of other countries to quickly improve the testing and contact tracing processes so we can better control the spread of the Covid-19 coronavirus. The more control and certainty we have, the more likely that things will get back to normal more quickly, especially regarding labor market supply and demand challenges. Before the American society can get to a sense of normalcy in the workplace, managers and leaders must deal with the reality of the "great resignation" during the transitionary period. 


\section{The Great Resignation}

The concept of great resignation describes the mass widespread trend of employees leaving their jobs to stay home to remain safe from any infections, to spend time with their family members, retire, or to get another more lucrative job during the Covid-19 coronavirus pandemic period. It is estimated that about 50\% of employees in some organizations and industries have left their jobs in 2021 (Maurer \& Mirza, 2021). As explained by Maurer and Mirza (2021) in their article published by the Society for Human Resources Management (SHRM), managers must work on findings which employees are quitting and why they are leaving voluntarily. Facts show that $40 \%$ of U.S. employees have been searching for new jobs or they plan to begin their search in the months or year to come. Of course, the Covid-19 pandemic has been a major driving force for this unexpected and massive exodus of employees toward other opportunities. The pandemic forced managers and their organizations to adjust their policies to the unique needs and diverse situations of their employees and customers. However, some managers did not effectively live up to the challenge in a timely manner and made unprofessional or unwise decisions; and therefore about $56 \%$ of employees considered searching for a new job because of their immediate managers (Maurer \& Mirza, 2021).

The massive resignation is being driven mostly by younger workers from Generation $\mathrm{Z}$ and Millennials, and employees of Hispanic and African American ethnic backgrounds are topping the list of those quitting their jobs. Due to their flexibility and expectations of higher standard and better compensation, younger workers and minorities tend to search for employment with competitive organizations that offer lucrative benefits and career development opportunities, along with flexibility for a better work-life balance. In some instances, during the Covid-19 pandemic, employees feel burnt out, excluded, and isolated from organizations as they have had to work from their homes; as such, managers must invest time in creating a supportive and inclusive work environment both face-to-face and in virtual work cultures to include colleagues who are working remotely (Delapenha, Espinosa, Fabre, Lemon, Gibson, \& Mujtaba, 2020).

According to Maurer and Mirza (2021), as well as personal discussions with working adults, the top reasons employees are quitting in pursuit of other opportunities are flexibility, career development and advancement, improved compensation, more work life balance, increased benefits, socially responsible reputation, and purposeful work. The Covid-19 pandemic has also given rise to the percentage of social loafers or disengaged workers; and, about $75 \%$ of disengaged employees are in search of new opportunities as they wait at their existing places of employment. It is known that personal and organizational factors can drive workers to become disengaged in their work, which eventually leads to voluntary turnover (Noe, Hollenbeck, Gerhart, \& Wright, 2019). This progression of withdrawal shows us that a typical employee, although not all, will demonstrate some behavioral changes as they physically or psychologically withdraw from their jobs. Employees withdraw and become disengaged for various rea- 
sons such as job dissatisfaction, perceptions of inequity or exclusion, and bad management practices. As a matter of fact, the unethical and unprofessional behavior of immediate bosses seems to be one of the major reasons for employee dissatisfaction and voluntary turnover. So, organizations must be careful not to promote individuals with questionable character into management positions. Also, managers must be regularly reminded to uphold the highest level of ethical standards since integrity (doing what you say you would do or walking your talk) is an essential trait for any respected leader.

We know that about 33\% of professionals who voluntarily left their jobs said that career advancement opportunities were their reason for the departure. The great resignation period of the Covid-19 pandemic has forced managers and modern companies to focus more on workforce planning and developing internal talent, especially when the external labor market is experiencing a huge talent scarcity and low unemployment rates. Research shows that about $94 \%$ of employees would stay in their current companies if career and employee development opportunities were formally prioritized by their managers and human resource departments (Bergeron, 2021).

Many firms offer formal education program opportunities, such as academic courses at universities, to make sure their employees are gaining the needed knowledge, competencies, and skills related to their immediate jobs and overall professions. It should be noted that some employees prefer outside of the classroom opportunities such as executive workshops, short training programs, job rotations, coaching, and formal mentoring options. For example, the hotel chain Hilton identified an education gap in around 5,000 of their employees; so, in 2015, they partnered with the Council for Adult \& Experiential Learning to develop a program that helped team members who wanted to pursue a GED or high school diploma (Hospitality for All, 2018). This program was fully paid for by the company and team members who chose to participate could get one-on-one coaching, tutoring and support from an academic advisor. Furthermore, Hilton developed a program called "Passport to Success for Hospitality," to create opportunities for young workers who wanted to develop their personal and professional skills within the hospitality industry. While partnering with The International Youth Foundation, managers at the Hilton corporation have been able to develop and train more than 8,200 workers in 14 countries (Hilton, 2021).

Overall, we know that this global pandemic of the past two years has increased the demands and expectations of the modern workforce from their employers, as workers now expect competitive wages, flexible and lucrative benefits, work-life balance, career progression options, and a significant investment in their development. Such benefits and opportunities will increase the number of applicants and employee retention percentages.

\section{Employee Hiring and Retention Realities}

The pandemic of 2020 caused many layoffs during the initial mandatory closures 
and quarantine periods since in some cases firms immediately lost about 80 - 90 percent of their revenues. For example, airlines had to stop most of their flights, which is their only means of generating revenues. While revenues declined, their fixed costs in terms of labor remained the same. As such, firms were required to reduce employee hours, furlough some of their workforce, provide lucrative voluntary separation packages, and/or lay off much of their workers to survive. Some of these decisions did not involve human resource professionals and/or were made without seriously or critically thinking about the damage that an ineffective reduction-in-force could do to the brand of the company in the long-term. Some employers did not realize that the market could get back to normal quickly or in matter of months and they would need their experienced people to continue offering their services to consumers. Of course, if the separations were not handled ethically and in a socially responsible manner, then many of the furloughed employees will probably choose to go to other firms, industries, and places of work rather than returning to their former employers. This is one of the reasons why recruiters are seeing that many job offers are now being declined by job seekers since the initial periods of mid-2020 when the U.S. labor markets began rebounding. While companies are trying to accommodate the needs of their customers and get back to business the way things were before the pandemic, they are still having a hard time getting sufficient applicants and retaining their workforce as job seekers are noticing more lucrative opportunities in their neighborhoods and beyond.

Regardless of how firms worked on their reduction-in-force goals, around the middle of 2020 until now in January of 2022, many firms began having to rehire some of their previously laid off or furloughed employees only to discover many were not coming back. Employers and human resources departments are discovering the recruiting new workers is now more difficult and harder than ever before. The unemployment rate in the United States is now less than $4 \%$, which means that job seekers have many choices regarding which jobs to take. Consequently, the Society for Human Resources Management (SHRM) explains that around $97 \%$ of the employers in such industries as the retail and hospitality are having a difficult time getting sufficient applications for frontline jobs. Of course, while demand is rising some employees have chosen to retire early to avoid getting infected, and recruiting is unlikely to get any simpler or easier in the short term. Employers and recruiting professionals in the human resources departments around the country are realizing that the psychological contract (especially job seekers' expectations) have changed dramatically. This change in job seekers expectations of better salary, flexibility, and an ideal work environment makes it essential that modern leaders and organizations, "develop a compelling employee value proposition that includes competitive compensation and meaningful benefits, especially career development opportunities and flexible work" (Maurer, 2021: p. 32). Therefore, many firms are reviewing and adjusting their job descriptions, increasing starting salaries, offering sign-in bonuses, en- 
couraging employee referral programs, enhance their benefits, making their work environments more fun, provide vaccine incentives, longer and more frequent leave policies, mental health counseling, childcare services, wellness programs on premises, massage hours, and use more user-friendly-technology to accommodate the needs of their employees and to make life easier for everyone through evidence-based decision-making.

With modern technology, many HR professionals are separating work that can be done by being present in the office versus tasks that can be done from home or even when people are on vacations with family. The effective use of modern technology allows more flexibility for organizations to retain their existing employees and recruit new ones from distances far away from their offices. It is very important that HR professionals are tech-savvy and speak the language of the modern generation to recruit and retain them. Ultimately, organizational agility to adopt quickly to the market and the psychological needs of their current employees, flexibility and good management practices will be key in the recruitment, productivity, and retention of top talent. While employee sign-in bonus programs are temporary and will eventually come to a halt as we see a balance between supply and demand and since it tends to be a lose-lose proposition for employers competing with each other, better and more competitive total compensation will remain for the years to come. As a matter of fact, after nearly thirty years of sluggish growth of about $3 \%$ annually for most years, we saw a 4.9\% compensation growth in October of 2021 (Maurer, 2021: p. 34). We are seeing more and more firms increasing salaries for the hard-to-fill positions which have remained open for a while. However, it should be noted that paying people more money is not a sustainable solution, since people also want flexibility in their schedules, good benefits, and an inclusive work culture that they can associate with and always take pride in the purpose of their existence. We know that money only provides temporary drive for people to join an organization or even to work harder at any given time.

Good compensation alone does not develop the commitment of employees to the organization's work, mission, or overall existence. While equitable and lucrative compensation is mandatory to recruit and hire people, it is having a developmental and inclusive organizational culture with good management and leadership that will make a difference in sustainable productivity and retention of top talent over time. The retail giant, Walmart, announced in 2021 that they would be investing over $\$ 1$ billion in the training and development of their most important asset, their human capital. Many employers are offering very good tuition reimbursement programs. Of course, some of these benefits are not new or novel as they have been around for many years to retain good employees. For example, for many years, Nova Southeastern University has been offering 100\% tuition reimbursement for qualified employees who earn their bachelor's degree and $80 \%$ tuition reimbursement for those who are earning their master's degrees. Many organizations are using programs like reskilling and upskilling their existing employees as a competitive strategy for productivity and employee re- 
tention. As emphasized by Maurer (2021: p. 39), "The pandemic is provoking employers to rethink traditional ways of operating-and to rethink talent acquisition... As candidates at all levels weigh opportunities differently and the competition for talent continues to intensify, companies will need to offer an employment experience that candidates prize."

It is the job of organizational leaders and immediate managers to provide all their workers a great employment experience by being inclusive, equitable and fair which can then enhance employee retention and referrals. It has been said that leaders can lead or influence others orally by speaking about their vision, in a written format by specifying the end goals through general means or a stepby-step format, and/or simply by being a good example. Of course, the best leaders and successful firms communicate the same message of inclusion and equity to all effectively through integrated marketing communication (IMC) orally and in writing, while also "practicing what they preach" to stay consistent with their core messages to all stakeholders (Mujtaba, Mesa, McGee, Mears, \& Moncada, 2020). The same is true about emergencies that require organizations to furlough or layoff employees. Whatever the circumstance, as we have learned from the Covid-19 pandemic challenges during the year of 2020 and 2021, any future furlough or layoff should be done with care, fairness, and equity. Managers and employers should also remember to provide an inclusive work environment and organizational culture for all and this must consciously include the remote workers who are getting their jobs done in a synchronous or asynchronous manner from their homes. After all, 1 in 7 jobs are now done remotely (CBS 60 Minutes, January 9, 2022). Since some workers are not used to remote work cultures, it is the responsibility of effective leaders, managers and HR professionals to remind "employees of the importance of maintaining certain levels of professionalism" which is very "important and requires lots of tact and superior communication skills" as these "traits will go a long way toward creating the desired environment without alienating workers who are still adjusting to returning to a physical workplace" (Agovino, 2021: p. 50). In these times of cultural shifts in management, it is important that HR professionals and managers "help workers adjust from working for a rule-based organization to working for one that trusts them to make sound judgement calls" regardless of whether they are at the office, home, or vacation (Parsi, 2021: p. 56).

The following sections explore some of the pros, cons and best practices related to layoffs amid crisis situations like the Covid-19 pandemic.

\section{Layoffs amid the Pandemic}

Most American businesses are currently experiencing a shortage of employees because some people have chosen not to work to protect themselves from any infections, others have left to other organization after they were furloughed or laid off, and yet others move from one job to another for better compensation. As such, many companies are having difficulty in recruiting and retaining work- 
ers in a sustainable manner. Sadly, some organizations did not handle their "reduction-in-force" (layoffs) effectively and eventually lost experienced and competent employees who went into other places to work.

The notion of layoffs ${ }^{1}$ and the incentives encouraging this practice is unique and peculiar for each organization. With unstable market conditions and dynamic external factors that strongly influence industries and their strength, the economy itself is heavily related to and dependent on the health of society (Mujtaba et al., 2020). Considering this elevated reliance on environmental and social wealth, severe consequences can arise when these elements are compromised (Korman \& Mujtaba, 2020; Bond \& Goldstein, 2015; Bergström \& Arman, 2016). With the rise and spread of Covid-19 throughout the planet, global economies have been compromised, forcing companies to shut down or engage in employee dismissals, also known as layoffs (Bolsu, 2020). A common practice, typically occurring when companies downsize, is using layoffs as a means to reduce overall expenses. However, with these actions come countless consequences for both the organization and the terminated employee.

While some organizations practice healthier discharge methods than others, all organizations should utilize human resource management professionals and effective practices to perform layoffs in the most comforting and effective manner possible to reduce the unnecessary distress during transitionary times (Tran, Tran, Nguyen, Mach, Phan, \& Mujtaba, 2020). Performing ethical layoff practices can help reduce the overall severe effects of mental, physical, social, emotional, and financial impact on the worker (Jones, 2020). While some companies provide immediate financial benefits and assure to retain all employees currently onboard, other organizations cut checks and remove countless number of positions (Rainey, 2020; Siemaszko, 2020; Tappe, 2020; Tarki, Levy, \& Weiss, 2020; Villa, 2020; Ylanmui, 2020). Nevertheless, there are enhanced techniques and approaches to downsizing that does not always require removal of talented personnel, even if only temporary. With certain employees being impossible to replace, having an abundance of knowledge and experience within the firm, and a general working environment that is fearful and concerned for their futures, overall productivity and effectiveness becomes highly reduced (Sucher \& Gupta, 2019). Considering the drastic changes within the economy due to Covid-19, subsequent information portrays how human resource professionals should conduct layoffs, and in addition, present healthier alternatives for downsizing as opposed to layoffs.

Generally, the rationale of downsizing and layoffs within a company is to save money in order to remain competitive and ultimately stay in business. While there are various reasons companies engage in downsizing, the main goal is usually to cut its expenses to retain more capital (Jones, 2020). Covid-19 created a business environment the world has never seen. Business came to a standstill, not because

${ }^{1}$ This material is based on the following article which provides a comprehensive overview: Korman, K. and Mujtaba, B.G. (2020). Corporate Responses to COVID-19 Layoffs in North America and the Role of Human Resources Departments. Reports on Global Health Research, 3(2), 1-17. 
of any change in technology or manufacturing location, and not from any wrongdoings that companies have done, but due to the natural current state. This makes the situation so problematic and uncertain, as we cannot compare this to any other previous event in history. Positive outcomes stemming from layoffs of Covid-19 will allow companies to preserve its cash so when the eventual return of the business, which should come after the virus passes, the company will be able to re-hire its employees and resume operations. Sadly, due to mistakes made during the layoffs, many employees in 2021 and early 2022 are not returning to the same firms where they worked prior to the pandemic. At the meantime, with a decrease in personnel, this gives an opportunity for current employees to have further responsibilities and be more productive (Mujtaba \& Senathip, 2020). Another positive factor from layoffs is the safety of workers and all personnel involved in the business. The Occupational Safety and Health Act (OSHA) states that each employer has a duty to give employees a place of employment, free from hazards that cause or likely to cause death or serious physical harm (Noe et al., 2019). Considering that the Covid-19 virus is highly contagious and extremely dangerous in certain cases, by reducing staff (including employees, manufacturers, suppliers), the spread of the virus will decrease, which vows for a slightly safer environment.

One of the most unfortunate drawbacks from the Covid-19 layoffs is that terminated employees can face a range of severe health consequences, which sometimes cause long-lasting effects such as financial consequences, emotional and social impact, as well the mental and physical concerns. Losing one's job is a challenging and desolate concept to grasp, as it directly affects one's mental states and has a significant amount of physical, social, financial, and emotional impact as well.

Mental impact. In general, depression, anxiety, and lack of confidence are common struggles for victims of layoffs. Harsh feelings of sadness and despair can at times develop into chronic mental health conditions that adults may endure for the remainder of their lives. It has been found that stress-related illnesses were $50 \%$ higher in the companies that downsized in the past, compared to companies that had not undergone downsizing (Mujtaba \& Senathip, 2020). This mental stress can be particularly extreme for the "breadwinners" of the families, as they have the role and responsibility of taking care of all their loves ones, while living on a tight budget.

Physical impact. Once employees are laid off and enter a state of stress and hopelessness, individuals are less likely to worry about their physical health or appearance. With less money to spend on gym or sports memberships, laid off personnel do not always have the means to improve their health. Consequently, the actual physical body is impacted, as backaches and low sexual desire are common physical symptoms of depression, along with extreme fatigue and a change in eating habits or sleep patterns (Walton, 2015).

Social impact. Since employees may experience heightened negative emotions 
after being laid off, personal and professional relationships can be impaired. While there is a direct correlation between layoffs and changes in one's social life, family ties and friendships are strongly affected. While a newly laid-off employee can experience feelings of anger, irritability, vulnerability, rejection, and helplessness, these feelings can spillover and spread amongst employees' loved ones, causing damage to family relationships. Since work typically provides structure within one's life, along with social connectedness and a feeling of self-worth, being terminated involves confronting the losses associated with social and psychological benefits.

Financial impact. One of the most influential consequences on laid off employees is the financial impact, which represents a main stressor, as individuals lose their principal source of income, which can lead to unwanted debt. Such circumstances leave employees and their families without adequate income over extended periods, resulting in higher levels of stress and more health symptoms (Ramlall \& Haas, 2020). Evidently, it is clear that the strength of financial implications is large, as the lack of revenue causes increased negative emotions and creates unfavorable changes in mental, physical, social, and emotional health.

Emotional impact. One of the most significant yet harmful impacts of layoffs during Covid-19 is the emotional concerns and consequences. As mental health experts believed that with all the closures and shutdowns, there will be a second wave to the coronavirus pandemic that is even harder to respond to or see: loneliness, sadness, depression, and even suicide (McCue, 2020).

Over the last two years, nations have gone through four waves of the Covid-19 infections, as many are seeing the rise of cases now due to the omicron variant. Unfortunately, the sentiments of loneliness, sadness, depression and sometimes other several illnesses are more difficult to detect, as they live within one's mind and can go unforeseen if not discussed. Moreover, without the opportunity to contribute to society and feel a sense of self-worth or purpose, adverse emotions become the new reality of terminated employees, as they remain uncertain of the future. Considering Covid-19 has rapidly and unexpectedly plagued the earth, we can deem this pandemic to be an uncontainable event, completely out of the employees' power. Being laid off due to these catastrophic reasons can result in individuals using escape coping strategies rather than positive, control-oriented coping strategies. Thus, the environmental influence causing the downsizings can naturally drive some people to cope with these discharges in a negative and unproductive way.

Apart from the terminated employee suffering harsh penalties from layoffs, an organization as a whole can experience punitive reactions from these practices. The situation and reality of employee layoffs can cause a fearful environment, as remaining employees are scared to lose their jobs. So, there are long-lasting, destructive implications not only for the terminated employee, but also for the entire organization and society in general (Jian et al., 2020). Organizations can try to prepare their furloughed and laid off employees to be engaged in constructive 
experiences as they wait to be recalled for work. If people remain productive and engaged in activities like going to school, earning a certificate that is important for one's profession, reading, walking, exercising, cooking, and learning new instruments or languages, this time in quarantine can allow individuals to not only cope with the stress, but also discover a life-fulfilling hobby they have never considered before. Acknowledging the present moment and being mindful is an increasingly important asset to hold, as companies such as Google and General Mills have started teaching mindfulness at their offices. Easier said than done, it is challenging for people to push themselves, especially in the middle of a pandemic. However, staying motivated and hopeful will lead laid off workers to new opportunities, possibly even better employment as most firms will eventually grow again, as is the case now in the United States. There were certain businesses and industries hiring during the initial spreading of Covid-19, including pharmacies, teleworking software, grocery stores, home delivery firms, government offices related to healthcare, and technology support positions (Stahl, 2020).

\section{HR Professional's Role in Layoffs}

In a laboratory study during the mid-1950s, Dr. Curt Richter conducted an experiment which demonstrates the importance of hope on attitude to keep on moving to survive. During a study, Richter (1957) placed rats in a pool of water to test how long they could tread water before they give up and die. On average, the rats would give up and sink after 15 minutes of swimming and treading water. However, right before the rats sink due to physical exhaustion and mental stress, the researchers would pluck them out of the water, dry them off, let them rest for a few minutes, and then put them back in for a second round of the experiment. In this second round, the rats were able to swim and tread water for an average of 60 hours. Since the rats were under the impression that they could eventually be rescued, they pushed their little bodies way past what they previously thought was impossible. As such, due to hope and the possibility of being rescued, the rats kept moving and treading water for much longer than their first attempt at survival. If hope can cause exhausted rats in such an experiment to swim for much longer, then what could a strong belief in oneself, one's abilities and one's company do for ourselves, our workers, and colleagues in the workplace? Managers, leaders, and, certainly, human resources professionals must be the conveyors of hope and a brighter future so their employees can keep on moving forward at high speeds like energetic sharks without looking back. The possibility of hope and a brighter future can strengthen employees' physical and emotional dexterity.

Typically, when conducting layoffs within a company, HR professionals must assist employees who are being laid off in finding new employment or offering them a temporary position at the company while each worker searches for new employment. At a minimum, HR professionals should provide hope for a brighter future for all employees, including those who are furloughed or laid off. 
However, during the start of the Covid-19 pandemic, this was not a feasible option for some firms, as the pandemic caused a universal and sudden loss of jobs due to immediate government-mandated closures. Without many options available, HR professionals cannot aid in finding new jobs for all laid off personnel.

Research has demonstrated that any layoff can cause lasting trust issues in an individual; and we know that job loss can result in weight gain, fatigue and weakened immune system for workers that must rethink their career options (Lamp, 2020). So, if you happen to be in a position of being involved in layoffs, remember to be transparent, show compassion, be kind, and offer as much support as you possibly can to employees who are negatively impacted by the terminations. At any time, dealing with layoffs should be handled very delicately and with the highest levels of professionalism. Varelas (2010) provides a number of practical recommendations that employers, managers, and HR professionals should use during those times; some of the recommendations include the following (Korman \& Mujtaba, 2020):

1) Have a well-thought-out plan. Organizations must understand that reorganization is imminent and must also seek legal counsel to understand and avoid any repercussions.

2) Remain objective. HR professionals should encourage managers to make decisions for layoffs based on legitimate reasons such as need and productivity instead of personal reasons.

3) Treat employees with respect and dignity. Always treat all employees with respect and give them the opportunity to leave with dignity.

4) Communicate clearly and honestly. Transparency during difficult times is respected and earns trust. HR professionals should ensure that the rumor mill does not damage the organization's reputation and negatively affect employee behavior.

5) Re-recruit remaining staff for additional responsibilities and promotions. When employees are laid off, remaining employees feel as if they could be the next ones gone in a future wave. HR professionals should help the organization support employees and explain just how their existence and roles will mold the future of the organization.

Human resource management (HRM) practices and jobs in all areas have been altered, changed or has somehow been affected by the impacts of Covid-19. The pandemic crisis forced individuals, families, workers, and organizations to depend on each other as well as the leaders that they have elected to bring cities, states, and nations through this dark time.

Overall, the pandemic closures of many businesses over the past two years along with many layoffs have proven to be a highly traumatic experience not only for the employees directly affected, but also for the remaining workers in the organization, management, and some of the customers. This explains why it is imperative for human resource professionals within the company to carefully orches- 
trate the practice of layoffs, to minimize the negative consequences and facilitate a successful economic journey throughout the layoff process. It is understandable that while providing a robust economic stimulus package might be necessary to assist those who have lost their jobs, it is not sufficient to curb the negative impact of Covid-19 on the economy and consumers; therefore, government policymakers should strategically assist hospitals, schools, and local leaders through a national and cohesive collective plan to effectively test, treat and trace the contacts of infected individuals so they can self-isolate in order to reduce and eliminate the spread of this virus. Of course, the testing and contact-tracing should be done much more efficiently, in a day or two, of noticing any symptoms.

\section{Conclusion}

The recent pandemic is still going strong as the latest omicron variant is spreading fast among everyone, including the fact that we are seeing more cases of breakthrough infections among the vaccinated. The good news is that the vaccines seem to be doing what they were designed to do, that is to prevent deaths and several illnesses from the infection.

One important lesson from the workforce layoffs of 2020 Covid-19 pandemic is that prior to executing a downsizing strategy or policy, managers and top executives need to involve human resources professionals so that they can accurately evaluate and determine which employees should be dismissed and which should remain for the business to continue operating as smoothly as possible. Taking into account the negative outcomes on the remaining workforce after the layoffs, managers should place substantial emphasis on the working staff. Among surviving employees, downsizing creates a high level of stress, along with poor morale and even guilt. Considering these unconstructive emotions, along with operations being altered due to missing personnel, HR should try to instill confidence in staff members, assure employees of their value to the organization, and communicate to all workers the company's reasons and rationale for the layoff. Moreover, throughout the process of layoffs, managers must keep communication open and honest in order to keep work relationships strong and prosperous. Employees must be able to trust their employers and managers, or group dynamics and teamwork can be negatively modified.

Like all other research studies, this paper has certain limitations as it is based on literature from publicly available sources and articles as well as the observation of the author. Since time is of essence to make the recommendations available, the author could not statistically analyze the data firsthand but rather focused on the effective management practices for acquiring and retaining a productive workforce. Another limitation is that the Covid-19 pandemic is ongoing, and situations change while article was being written, peer reviewed, updated, and finalized. Despite all the limitations, the main contribution of this research is to help managers and organizations have an inclusive organization culture where employees are welcomed, included in major decisions, and treated with 
respect so that they can avoid jumping ship for the next big opportunity during these low unemployment periods in the United States.

Overall, the author encourages all leaders to first work on preventing the spread of Covid-19 coronavirus as this is the best way for the economy to go back to some sense of normalcy more quickly. Consequently, we must be focused on prevention first and then the stimulation of the economy as well as regular operations of government offices, businesses and schools. If little kids can be in school during the Covid-19 virus, then adults can certainly return to work by exercising proper social distancing protocols, washing their hands regularly, wearing masks, and being vaccinated.

\section{Conflicts of Interest}

The author declares no conflicts of interest regarding the publication of this paper.

\section{References}

Agovino, T. (2021). What You Need to Succeed: Five Essential Traits HR Professional Must Have Not. HR Magazine, 66, 48-53.

Bergeron, P. (2021, October 4). Hold on to Your High Potential Workers: Identify Your Top Performers before They Leave Post Pandemic. SHRM.

https://www.shrm.org/resourcesandtools/hr-topics/organizational-and-employee-devel opment/pages/hold-on-to-your-high-potential-workers.aspx

Bergström, O., \& Arman, R. (2016). Increasing Commitment after Downsizing: The Role of Involvement and Voluntary Redundancies. Journal of Change Management, 17, 1-24. https://doi.org/10.1080/14697017.2016.1252784

Bolsu, R. (January 2020). 7 HR Tips for Handling Employee Layoffs. https://blog.namely.com/blog/7-hr-tips-for-handling-employee-layoffs

Bond, P., \& Goldstein, I. (2015). Government Intervention and Information Aggregation by Prices. The Journal of Finance, 70, 2777-2812. https://doi.org/10.1111/jofi.12303

Delapenha, C., Espinosa, C., Fabre, J., Lemon, P., Gibson, N., \& Mujtaba, B. G. (2020, August). The SAS Institute's Human Resources Practices in Diversity and Inclusion. Journal of Human Resource and Sustainability Studies, 8, 249-265. https://doi.org/10.4236/jhrss.2020.83014 https://www.scirp.org/journal/paperinformation.aspx?paperid=102082

Hilton (2021). Creating Opportunities for Youth in Hospitality. Hilton Worldwide Global Media Center. http://news.hiltonworldwide.com/index.cfm/misc/youth-programs

Hospitality for All (2018). Great Place to Work. https://www.greatplacetowork.com/images/reports/2018-GPTW-Profile-Series- Hilton Hospitality For All.pdf

Jian, Z., Wang, X., Wang, H., Lu, G., Wang, G., Zhang, X., \& Gong, X. (2020). The Impact and Opportunities of COVID-19 on China. Journal of Service Science and Management, 13, 558-566. https://doi.org/10.4236/jssm.2020.133036

Jones, C. (2020, March 31). What 47 Million People Being Laid off Looks Like. https://www.forbes.com/sites/chuckjones/2020/03/31/what-47-million-people-being-la id-off-looks-like/\#6c5ad5af58b8

Korman, K., \& Mujtaba, B. G. (2020). Corporate Responses to COVID-19 Layoffs in North America and the Role of Human Resources Departments. Reports on Global 
Health Research, 3, 1-17. https://doi.org/10.29011/2690-9480.100122

https://www.gavinpublishers.com/articles/review-article/Reports-on-Global-Health-Re search/corporate-responses-to-covid-19-layoffs-in-north-america-and-the-role-of-hu man-resources-departments

Lamp, M. (2020). How to Manage Layoffs Humanely and Remotely during COVID-19. https://jobbatical.com/resources/how-to-manage-layoffs-humanely-and-remotely-duri ng-covid-19

Maurer, R., \& Mirza, B. (2021, September 12). Deconstructing the Great Resignation: SHRM Research Reveals Which Employees Are Leaving and Why. SHRM.

https://www.shrm.org/hr-today/news/hr-news/pages/deconstructing-the-great-resignat ion.aspx

Maurer, R. (Winter 2021). Great Expectations: Emboldened by a Pandemic-Fueled Talent Shortage, Job Candidates Are Asking for the Moon-And Often Getting It. HR Magazine, 66, 32-39.

McCue, T. J. (2020, April 30). Sadness and Loneliness: Here Is How You Can Fight Them during 2020 Shutdowns. Forbes.

https://www.forbes.com/sites/tjmccue/2020/04/30/sadness-and-loneliness-here-is-how -you-can-fight-it-during-2020-shutdowns/\#3435a2ce4892

Mujtaba, B. G., \& Senathip, T. (2020). Layoffs and Downsizing Implications for the Leadership Role of Human Resources. Journal of Service Science and Management, 13, 209-228. https://www.scirp.org/journal/paperinformation.aspx?paperid=99284 https://doi.org/10.4236/jssm.2020.132014

Mujtaba, B. M., Mesa, N. F., McGee, S., Mears, S. O., \& Moncada, F. S. (2020, November). Distinctive HR Policies and Practices to Create a Workplace "Where Working Is a Pleasure" amid the Covid-19 Pandemic: The Organizational Culture of Publix Super Markets, Inc. International Journal of Human Resource Studies, 10, 125-128.

http://www.macrothink.org/journal/index.php/ijhrs/issue/view/1012 https://doi.org/10.5296/ijhrs.v10i4.17888

Noe, R. A., Hollenbeck, J. R., Gerhart, B., \& Wright, P. M. (2019). Human Resource Management: Gaining a Competitive Advantage (11th ed.). McGraw-Hill.

Parsi, N. (2021). People First: Kate Gebo Is Helping to Spearhead a Culture Change That Empowers Workers at United Airlines. HR Magazine, 66, 54-59.

Rainey, R. (2020, April 16). Jobless Claims Reach 22 Million over Four Weeks. https://www.politico.com/news/2020/04/16/coronavirus-unemployment-claims-numb ers-190026

Ramlall, S., \& Haas, H. (2020). The Impact of Layoffs. Hamline University-News.

Richter, C. P. (1957). On the Phenomenon of Sudden Death in Animals and Man. Psychosomatic Medicine, 19, 191-198.

https://www.aipro.info/wp/wp-content/uploads/2017/08/phenomena sudden death.p df

https://doi.org/10.1097/00006842-195705000-00004

Siemaszko, C. (2020, April 20). Disney Furloughs 100,000 Theme Park and Hotel Workers amid Coronavirus Shutdown. NBC News.

https://www.nbcnews.com/news/us-news/disney-furloughs-100-000-theme-park-hotel -workers-amid-coronavirus-n1188236

Stahl, A. (2020). 4 Industries That Are Still Hiring in the Midst of Covid-19. Forbes. https://www.forbes.com/sites/ashleystahl/2020/04/01/4-industries-who-are-still-hiringin-the-midst-of-covid-19/\#a49b62015eee

Sucher, S. J., \& Gupta, S. (2019, August 23). A Better, Fairer Approach to Layoffs. 
https://hbr.org/2018/05/layoffs-that-dont-break-your-company

Tappe, A. (2020, April 23). Another 4.4 Million Americans Filed for Unemployment Benefits Last Week.

https://www.cnn.com/2020/04/23/economy/unemployment-benefits-coronavirus/inde $\underline{\text { x.html }}$

Tarki, A., Levy, P., \& Weiss, J. (2020). The Coronavirus Crisis Doesn't Have to Lead to Layoffs. Harvard Business Review, 2-6.

https://hbr.org/2020/03/the-coronavirus-crisis-doesnt-have-to-lead-to-layoffs

Tran, C. T. H., Tran, H. T. M., Nguyen, H. T. N., Mach, D. N., Phan, H. S. P., \& Mujtaba, B. G. (2020). Stress Management in the Modern Workplace and the Role of Human Resource Professionals. Business Ethics and Leadership, 4, 26-40.

https://doi.org/10.21272/bel.4(2).26-40.2020

https://armgpublishing.sumdu.edu.ua/journals/bel/volume-4-issue-2/article-3

Varelas, E. (2010). 10 Strategies for Dealing with Layoffs. HR Exchange Network.

https://www.hrexchangenetwork.com/hr-talent-management/articles/10-strategies-fordealing-with-layoffs

Villa, L. (2020, March 30). Millions of Americans Have Been Laid Off amid the Coronavirus Outbreak. Here's What It's Like to Be One of Them.

Walton, A. (2015). Depression Isn't Always What You Think: The Subtle Signs. Forbes. https://www.forbes.com/sites/alicegwalton/2015/02/17/the-subtle-symptoms-of-depres sion/\#71a29ce71a3e

Ylanmui (2020, April 22). Massive Layoffs and Pay Cuts Are Likely Coming to State and Local Governments as Federal Aid Goes Elsewhere.

https://www.cnbc.com/2020/04/22/coronavirus-relief-bill-layoffs-coming-to-state-local -governments.html 